\title{
GEOGRAPHIC VARIATION AND SPECIATION IN THE SOSIPPUS FLORIDANUS SPECIES GROUP (ARANEAE: LYCOSIDAE)*
}

\author{
By Allen R. Brady \\ Hope College \\ Holland, Michigan 49423
}

\section{INTRODUCTION}

In March, I959, while collecting in Goose Island State Park in Aransas County, Texas, I encountered the lycosid genus Sosippus for the first time. I collected four immature specimens that appeared to be an unfamiliar species of Agelenopsis, more darkly colored than most but with a similar color pattern and running upright over a sheet-web with a funnel-shaped retreat. Later when examining these specimens under a dissecting microscope, I was surprised to find a typical lycosid eye arrangement and other diagnostic features of the Lycosidae. My initial interest in Sosippus was in its web-building behavior and the possibility that this genus might be intermediate in position between the Agelenidae (whose habits it parallels) and the Lycosidae (whose structural features it exhibits).

The Lycosidae, or wolf-spiders, are one of the most successful families of spiders. Most of them are ground dwelling forms that rarely use silk to capture their prey. Instead they rely upon their keen sense of touch, long, well-developed legs and powerful chelicerae to capture their prey. Many wolf spiders tend to wander in search of food, others hunt in the vicinity of their retreats which they only leave at night.

The Lycosidae are adapted to a great variety of habitats and are represented by an abundance of individuals in these habitats. They are particularly interesting from the viewpoint of comparative systematics since many species populations are found over a wide geographic range including a diversity of habitats. For example, $L y$ cosa carolinensis ranges from New England to southern Florida and westward to the Sonoran desert. This species changes little in such diagnostic features as the shape of the epigynum and the structure of the palpus, but does become lighter in color from north to south and east to west. As a general rule few taxonomic differences have been reported in widespread species populations of Lycosa.

Geographic Variation and Speciation. In 1959 C. F. Roewer

\footnotetext{
*Manuscript received by the editor April 3, 1972.
} 
TABLE 1

\begin{tabular}{|c|c|c|c|}
\hline SPECIES & LOCALITY & $\begin{array}{l}\text { CHELLICERAL } \\
\text { TEETH } \\
\end{array}$ & EPIGYNUM \\
\hline MIMUS & FOUNTAINBLEAU & $\begin{array}{l}3-3(11) \\
3-4(3) \\
4-2(1)\end{array}$ & \\
\hline FLORIDANUS & CEDAR KEY & $\begin{array}{ll}4-4 & (33) \\
5-4 & (1)\end{array}$ & \\
\hline JANUS & LAKE LOCHLOOSA & $\begin{array}{ll}4-4 & (21) \\
4-3 & (4) \\
4-5 & (1) \\
5-3 & (1)\end{array}$ & \\
\hline PLACIDUS & LAKE PLACID & $\begin{array}{ll}3-3 & (8) \\
4-3 & (2)\end{array}$ & $\$$ \\
\hline \multicolumn{4}{|c|}{$\begin{array}{c}\text { COMPARISON OF SELECTED } \\
\text { POPULATIONS }\end{array}$} \\
\hline
\end{tabular}

published the third volume in a series of monographs dealing with the classification of the Lycosidae of the world. Roewer (1959) separated Sosippus into two genera: Sosippus, in a restricted sense, and Sosippinus, a new genus. This separation was based on the number of posterior cheliceral teeth. Employing this criterion Sosippus mimus and $S$. floridanus were placed in separate genera. As shown in my earlier paper (Brady, 1962) this division into two genera on the basis of number of posterior cheliceral teeth was clearly an artificial device. In most genera of the Family Lycosidae the number of posterior cheliceral teeth is relatively constant, 3-3 (three on each side) being the most common pattern. In the genus Sosippus, however, specimens from a single population may have 4-3, 4-4, 4-5, or 5-3 posterior cheliceral teeth (see Table I). This simply illustrates that a single character difference cannot be indiscriminately applied, particularly in separating genera. From my initial investigation in 1962, it became clear that Sosippus was represented by one species, $\mathcal{S}$. californicus, in the southwestern United States, but the picture was less clear in the southeastern United States. 
Sosippus can readily be divided into two species groups based upon their morphology, coloration, genitalic structure, and geographic distribution. One species group is found in the West and consists of $S$. californicus and four Mexican species. In the East I recognized three species in the second group in I962: S. texanus, $S$. mimus, and $S$. floridanus. This paper is primarily a more detailed examination of the southeastern populations which make up the $S$. Aoridanus species group. Two perplexing features of the distribution and geographic variation of Sosippus mimus appeared in I962. First was the occurrence of specimens from northern Florida which had a color pattern like mimus, but possessed 4-4 posterior cheliceral teeth as in floridanus. Second was the occurrence of three specimens from Lake Placid, Florida (including only a single mature female, figs. I3-I 4 of Brady, I962) that were not like any of the specimens from surrounding localities. Based on their color pattern and 3-3 posterior cheliceral teeth, these were considered southern representatives of mimus (see Map I, Brady, I962).

The occurrence of a few isolated specimens of mimus in southern Florida was most puzzling. Also the variability of certain characters in mimus from northern Florida indicated the possibility that more than one species was represented. The materials available in 1962 included only three mature specimens between Louisiana and western Florida, all males. It is very difficult to distinguish different species of the floridanus group on the basis of males alone. The primary problem, then, was the lack of specimens from critical areas.

Since I96I a number of short field trips to Florida of 5-7 days duration have provided additional data. After a preliminary trip to Florida during the spring of I968, Jim Toothaker and I undertook an intensive three week field study during which we collected and photographed Sosippus from Louisiana to south central Florida.

From the western-most locality where we collected Sosippus (Fountainbleau State Park near Mandeville, Louisiana) to Youngstown in western Florida, we found only one species, S. mimus. Characteristic of this species was a relatively constant number of 3-3 posterior cheliceral teeth (Table I), a diffuse color pattern on the carapace (Figs. 28-33) and a specific type of epigynum (Figs. I-9).

Along the west coast (Cedar Key) and inland (Horse Creek) in peninsular Florida, we found typical $S$. floridanus. These populations all have 4-4 cheliceral teeth on the posterior margin (Table I), a characteristic floridanus color pattern with the white stripes 


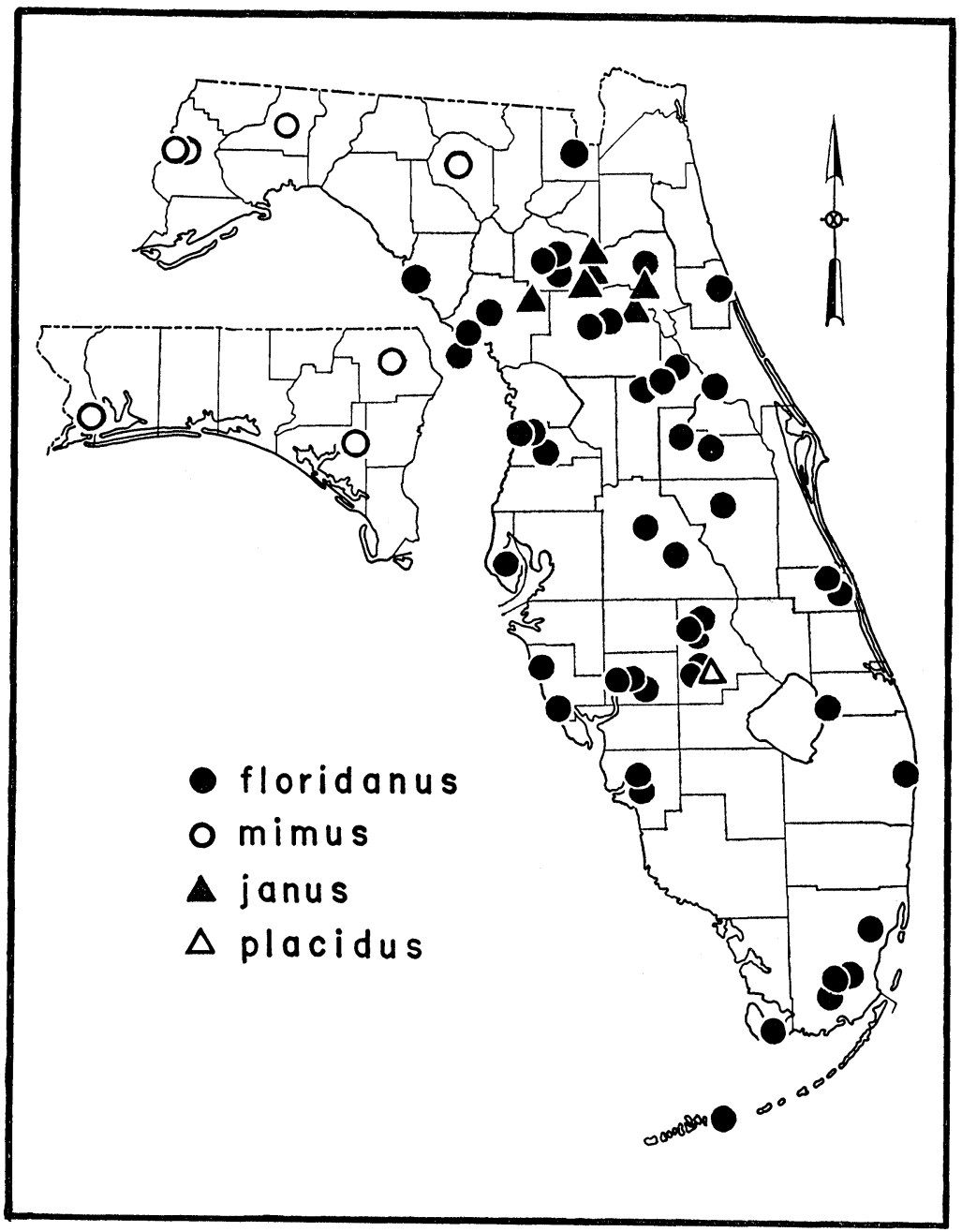


contrasting sharply with the black background of the carapace (Figs. 34-38), and a peculiar epigynum (Figs. IO-I3, I9-24).

At Lake Lochloosa we encountered a population with a predominant 4-4 tooth pattern (Table I), but with an unusual and somewhat variable epigynal structure (Figs. I4-I8), and a more diffuse color pattern than $S$. floridanus, the white or yellowish markings on the carapace not contrasting sharply with the black background of the carapace (Figs. 4O-4I ). The available data below indicate that this is a distinct population and it is recognized here as $S$. janus.

At Lake Placid, in south central Florida, we made our most interesting discovery. Here we found a population of large specimens, unique in color pattern (Fig 39), epigynal structure (Figs. 25-27), and with 3-3 posterior cheliceral teeth (Table I). This population is designated $S$. placidus and described below.

From the investigation made in 1968 and information gathered since, it is evident that there are populations of Sosippus in peninsular Florida that are quite different from mimus and floridanus. The distribution patterns of different populations of Sosippus in Florida appear to reflect recent geologic events. Sosippus placidus is restricted to an area represented by Red Hill Island of the Aftonian Interglacial (Laessle, I958).

The rise in sea-level during the Pleistocene with the concomitant production of various islands where the Florida peninsula now stands has influenced speciation in at least three different genera of spiders. The influence of Pleistocene events is seen in the distribution patterns of certain species of Geolycosa (McCrone, 1963), Latrodectus (McCrone and Levi, I964), and Sosippus (Map I). In considering the series of events producing differentiation in these spiders, several factors need to be emphasized. First it would seem that saltwater currents served as an effective barrier to gene flow so that divergence of the populations could proceed. I think that these barriers, by themselves, would be insufficient to account for the reproductive isolation of these populations. Even where the spiders have limited dispersal powers (as in Geolycosa) other factors must have been in operation. I suggest that the reduction of population numbers on the Pleistocene islands with a corresponding reduction in genetic variability played a significant role in the process of speciation. These geographical isolates became genetically homogeneous and ecologically specialized for the xerophytic conditions of the Pleistocene islands. Even today the limits of the species ranges of thesc spiders is prescribed by the extent of the xeric communities 


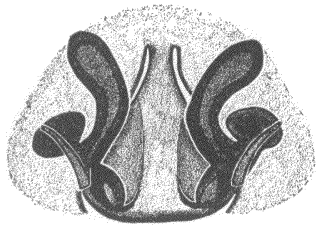

1

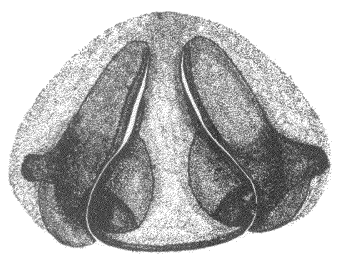

4

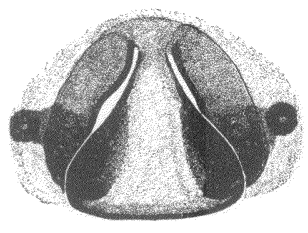

7

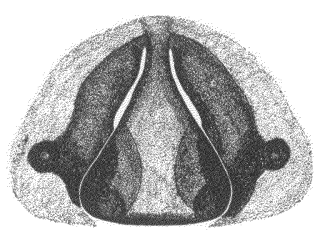

2

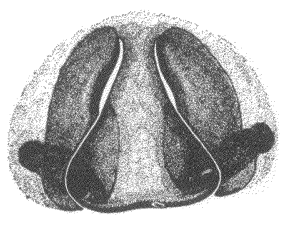

5

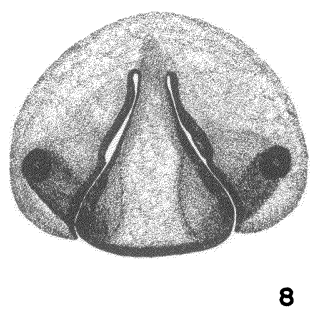

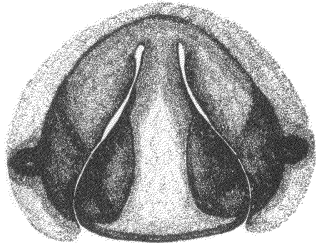

3

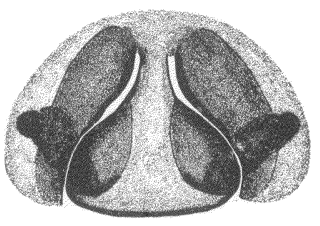

6

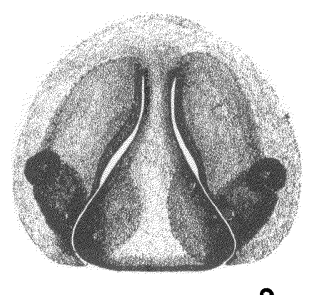

9

Figs. 1-4. Sosippus mimus Chamberlin, from Fountainbleau St. Pk. near Mandeville, St. Tammany Par., Louisiana, 17-18 June 1968. 1. Internal genitalia, dorsal view. 2-4. Epigyna, showing variation.

Figs. 5-7. Epigyna of Sosippus mimus Chamberlin from Magnolia St. Pk. near Biloxi, Jackson Co., Mississippi, 18 June 1968, showing variation. Figs. 8-9. Epigyna of Sosippus mimus Chamberlin from $7 \mathrm{mi}$. S. of Youngstown, Bay Co., Florida, 20 June 1968, showing variation. 
formed from these islands. When the islands were joined after the Pleistocene, the insular populations were effectively isolated ecologically and reproductively.

\section{ACKNowledgements}

For my initial investigation of Sosippus in 1962, I used the collections of the Museum of Comparative Zoology, Harvard University, and those of the American Museum of Natural History, New York, supplied by Dr. Willis Gertsch. In addition, Dr. H. K. Wallace of the University of Florida and Dr. Joseph A. Beatty, presently of Southern Illinois University, supplied much needed specimens.

The present study was aided by specimens kindly supplied by Dr. H. K. Wallace of the University of Florida and Dr. H. W. Levi of the Museum of Comparative Zoology. I express my appreciation to individuals and institutions for their aid in this investigation.

Special thanks go to Jim Toothaker, formerly a student at Hope College, who aided considerably in the collection of data and photography. A note of appreciation goes to Dr. Howard V. Weems, Jr. and the Bureau of Entomology, Florida Department of Agriculture for supplying the map of Florida. I also wish to thank Dr. H. W. Levi for reading critically the manuscript. National Science Foundation grant number GB-I3925 helped to defray expenses of this research.

\section{Taxonomic Section}

Sosippus floridanus Simon

Figures IO-13, 19-24, 34-38. Map I.

Sosippus floridanus Simon, 1898, Ann. Soc. Ent. Belgique, 42: 25. Female holotype from Florida in the Paris Museum. Roewer, 1954, Katalog der Araneae, 2: 314. Bonnet, 1958, Bibliographia Araneorum, 2(4): 4093. Roewer, 1959, Exploration du Parc National de l'Upemba, Araneae Lycosaeformia II (Lycosidae), P. 1004. Brady, 1962, Psyche, 69(3): 151, figs. 1, 19, 20, 40-43, map 1 .

Discussion. For structural details, coloration, preliminary diagnosis, and natural history refer to Brady (1962). Unlike the records for $S$. mimus, which represent several species, those listed in 1962 for $S$. floridanus represent that species only.

New records are listed below.

Diagnosis. In addition to the features mentioned previously $\mathcal{S}$. floridanus may also be distinguished from $S$. mimus by the number of posterior cheliceral teeth (Table I). Sosippus floridanus is most similar to $S$. janus. It may be distinguished from the later species 


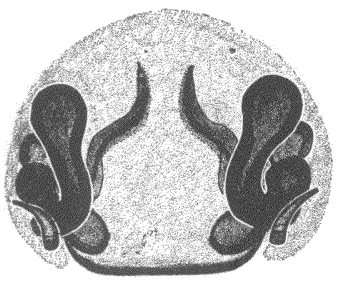

10

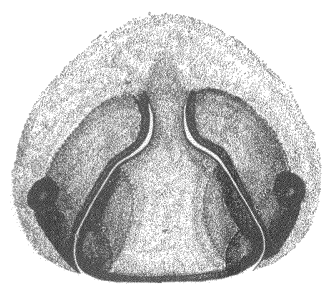

13

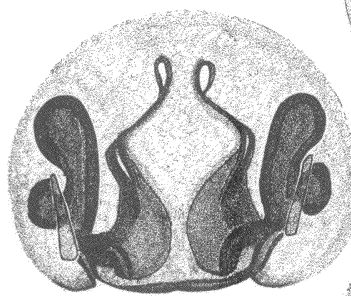

16

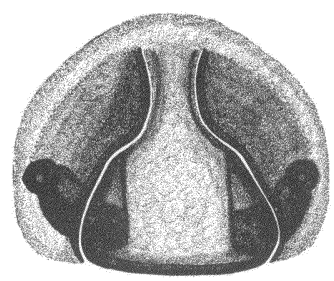

11

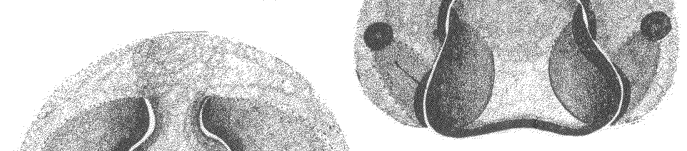

14

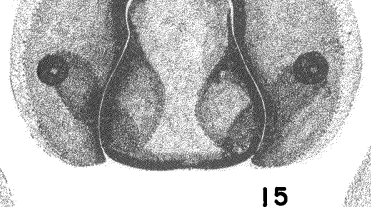

15

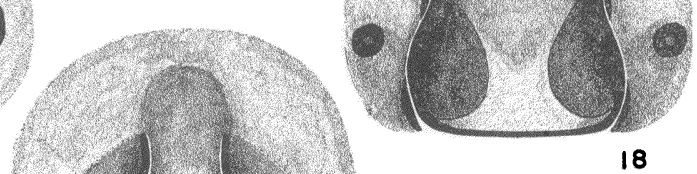

12
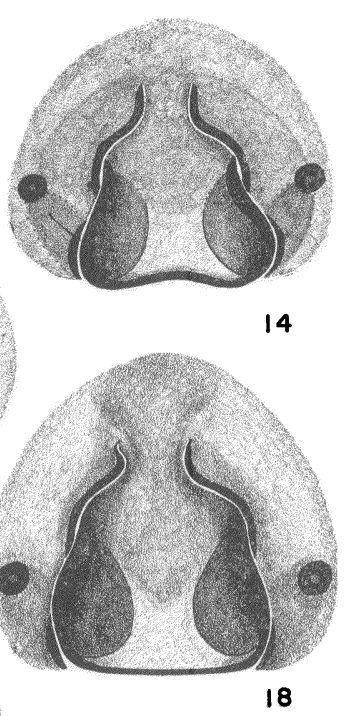

17

Figs. 10-13. Sosippus floridanus Simon, from Cedar Key, Levy Co., Florida, 9 June 1968. 10. Internal genitalia, dorsal view. 11-13. Epigyna, showing variation.

Figs. 14-18. Sosippus janus sp. n., from NW shore of Lake Lochloosa, Alachua Co., Florida, 11 Apr. and 10 June 1968. 14-15. Epigyna, showing variation. 16. Internal genitalia, dorsal view. 17. Epigynum of female holotype. 18. Epigynum, showing variation. 
by color pattern (compare Figs. 34-38 with Figs. 4O-4I), the form of the epigynum (compare Figs. IO-I3, I9-24 with Figs. 14-18), and ecological attributes. Sosippus floridanus is found most often in Pine-Palmetto associates (Fig. 42) or similar rather dry habitats, while $S$. janus has been found only in mesic woods (Fig. 43).

Distribution. Southern Georgia and peninsular Florida into the Florida Keys (Map I).

New Records. GEORGIA. Crisp Co.: $7.3 \mathrm{mi} \mathrm{N}$ of Cordelle, 30 May 1964 우 (A. R. Brady). FLORIDA. County Records: Baker, Brevard, Dade, Dixie, Hernando, Marion, Palm Beach, Pinellas, Putnam.

\section{Sosippus texanus Brady}

Sosippus texanus Brady, 1962, Psyche, 69(3): 160, figs. 4, 21, 22, 37-39, map 1. Female holotype from Goose Island State Park, Aransas Co., Texas, 15 June 1961 (A. R. Brady) in the Museum of Comparative Zoology.

Discussion. For structural details, illustrations, preliminary diagnosis, and natural history, refer to Brady (1962).

Diagnosis. Sosippus texanus is most similar to $S$. mimus in coloration and has the same number of posterior cheliceral teeth. It is distinguished from $S$. mimus by its larger average size and the structure of the female epigynum (compare figs. 21,22 to figs. I5, I6 of Brady, 1962).

Distribution. Southern Texas.

New Record. TEXAS. Hidalgo Co.: Bentsen Rio Grande St. Pk., $6 \mathrm{mi}$. SW of Mission, 29 June $196240^{x} 0^{x}:$ 우우 : o (A. R. Brady).

\section{Sosippus mimus Chamberlin}

Figures I-9, 28-33. Map I.

Sosippus mimus Chamberlin, 1924, Proc. U.S. Nat. Mus. 63: 27, pl. 6, fig. 43. Female holotype from Mandeville, Louisiana, 1 May 1921 (H. E. Hubert) in Museum of Comparative Zoology. Comstock, 1940, The Spider Book, p. 639. Bonnet, 1958, Bibliographia Araneorum, 2(4) : 4093. Brady, 1962, Psyche 69(3): 156, figs. 15, 16 only, not figs. $13,14,17$.

Sosippinus mimus: Roewer, 1954, Katalog der Araneae 2: 313; 1959, Exploration du Parc National de l'Upemba, Araneae Lycosaeformia II (Lycosidae), p. 1002.

Discussion. Figures 13 and I4 of Brady (1962) are of Sosippus placidus. Figure I 7 is $S$. janus. In 1962 I indicated that the speci- 


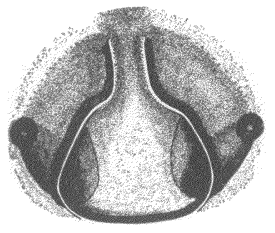

19

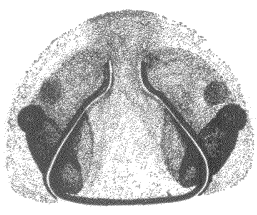

22

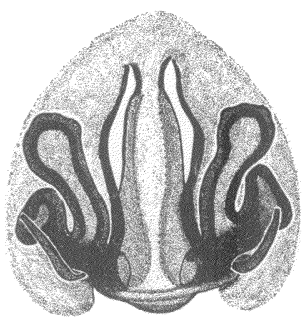

25

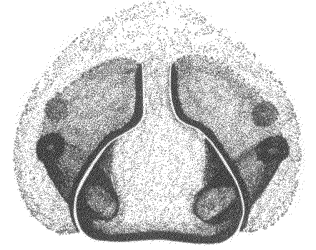

20

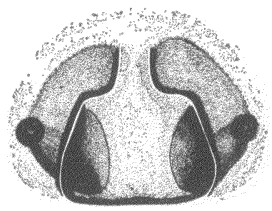

23

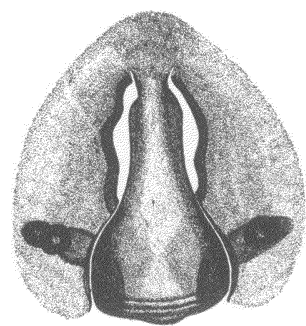

26

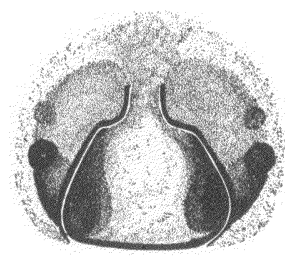

21

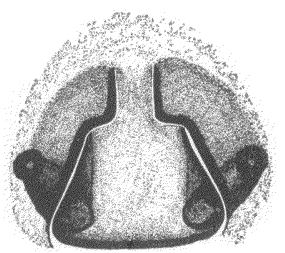

24

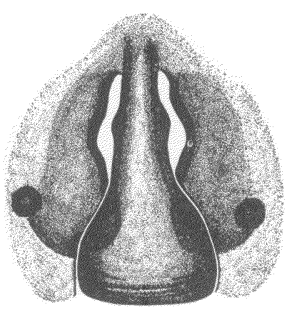

27

Figs. 19-24. Epigyna of Sosippus floridanus Simon showing variation. 19-20. Aripeka, Hernando Co., Florida, 13 June 1968. 21-22. One mile E of Horse Creek on St. Highway 72, Desoto Co., Florida, 12 June 1968. 23-24. Highlands Hammock St. Pk., Highlands Co., Florida, 19 June 1962.

Figs. 25-27. Sosippus placidus sp. n., from $6 \mathrm{mi}$. S of Lake Placid, Highlands Co., Florida, 12 June 1968. 25. Internal genitalia, corsal view. 26. Epigynum, showing variation. 27. Epigynum of female holotype. 
mens considered under $S$. mimus could well constitute more than one species. It is now apparent that at least three species were represented. Diagnostic measurements of $S$. mimus and the report on the number of cheliceral teeth in 1962 should be disregarded. The color description and pattern illustrated were of the type female of

$S$. mimus and remain valid.

Measurements: Total body length of two males from the type locality II.5, II.9 mm. Carapace width $4.3,4.4 \mathrm{~mm}$, carapace length $5.7,5.9 \mathrm{~mm}$.

Width of anterior eye row I.05, I.25 mm. Posterior ocular quadrangle: PME width I.IO $\mathrm{mm}$, PLE width $1.58 \mathrm{~mm}$, POQ length $\mathrm{I} . \mathrm{OO} \mathrm{mm}$.

Leg IV: femur $6.1,6.2 \mathrm{~mm}$, patella-tibia $7.6,7.8 \mathrm{~mm}$, metatarsus 7.2, $7.4 \mathrm{~mm}$, tarsus $3.4,3.5 \mathrm{~mm}$, total length $24.3,24.9 \mathrm{~mm}$.

Patella-tibiae: I 6.8, $7.2 \mathrm{~mm}$, II 6.5, $6.9 \mathrm{~mm}$, III 5.8, 6.0 mm.

Total body length of Io females from the type locality I2.5-I8.2 $\mathrm{mm}$, mean I $4.93 \mathrm{~mm}$. Carapace width $4.3-5.6 \mathrm{~mm}$, mean $4.9 \mathrm{I} \mathrm{mm}$, carapace length $5 \cdot 7-7.7 \mathrm{~mm}$, mean $6.7 \mathrm{I} \mathrm{mm}$.

Width of anterior eye row I.38-I.70 mm, mean $1.535 \mathrm{~mm}$. Posterior ocular quadrangle: PME width I.I8-I.43 mm, mean I.278 $\mathrm{mm}$, PLE width I.75-2.I $8 \mathrm{~mm}$, mean $1.920 \mathrm{~mm}$, POQ length r.o5I.28 mm, mean I.I63 $\mathrm{mm}$.

Leg IV: femur 5.4-6.9 mm, mean $6.22 \mathrm{~mm}$, patella-tibia 6.3$8.3 \mathrm{~mm}$, mean $7.36 \mathrm{~mm}$, metatarsus $5.6-7.2 \mathrm{~mm}$, mean $6.44 \mathrm{~mm}$, tarsus 2.7-3.5 mm, mean $3.13 \mathrm{~mm}$, total length $20.0-25.7 \mathrm{~mm}$, mean 23.15 $\mathrm{mm}$.

Patella-tibiae: I $5.7-7.5 \mathrm{~mm}$, mean $6.57 \mathrm{~mm}$, II $5.3-6.8 \mathrm{~mm}$, mean 6.19 mm, III 4.5-6.2 mm, mean $5.42 \mathrm{~mm}$.

Diagnosis. Sosippus mimus is like $S$. texanus in color pattern and number of posterior cheliceral teeth. It is distinguished from $S$. texanus by the structure of the female epigynum (compare Figs. I-9 with figs. 21, 22 of Brady, I962). Specimens of $S$. texanus are larger in average size.

Sossippus mimus is easily separated from $S$. floridanus by the number of posterior cheliceral teeth (Table I), color pattern (compare Figs. 28-33 with Figs. 34-38), and epigynal structure (compare Figs. I-9 with Figs. IO-I3, I9-24).

Natural History. Sosippus mimus was collected from regions of sandy soil in wooded areas and in more or less open fields from eastern Louisiana to western Florida from I 7-20 June, I968. Like other species of Sosippus it occurred commonly in disturbed habitats, for example, fields that had been cleared for construction, fire breaks, 

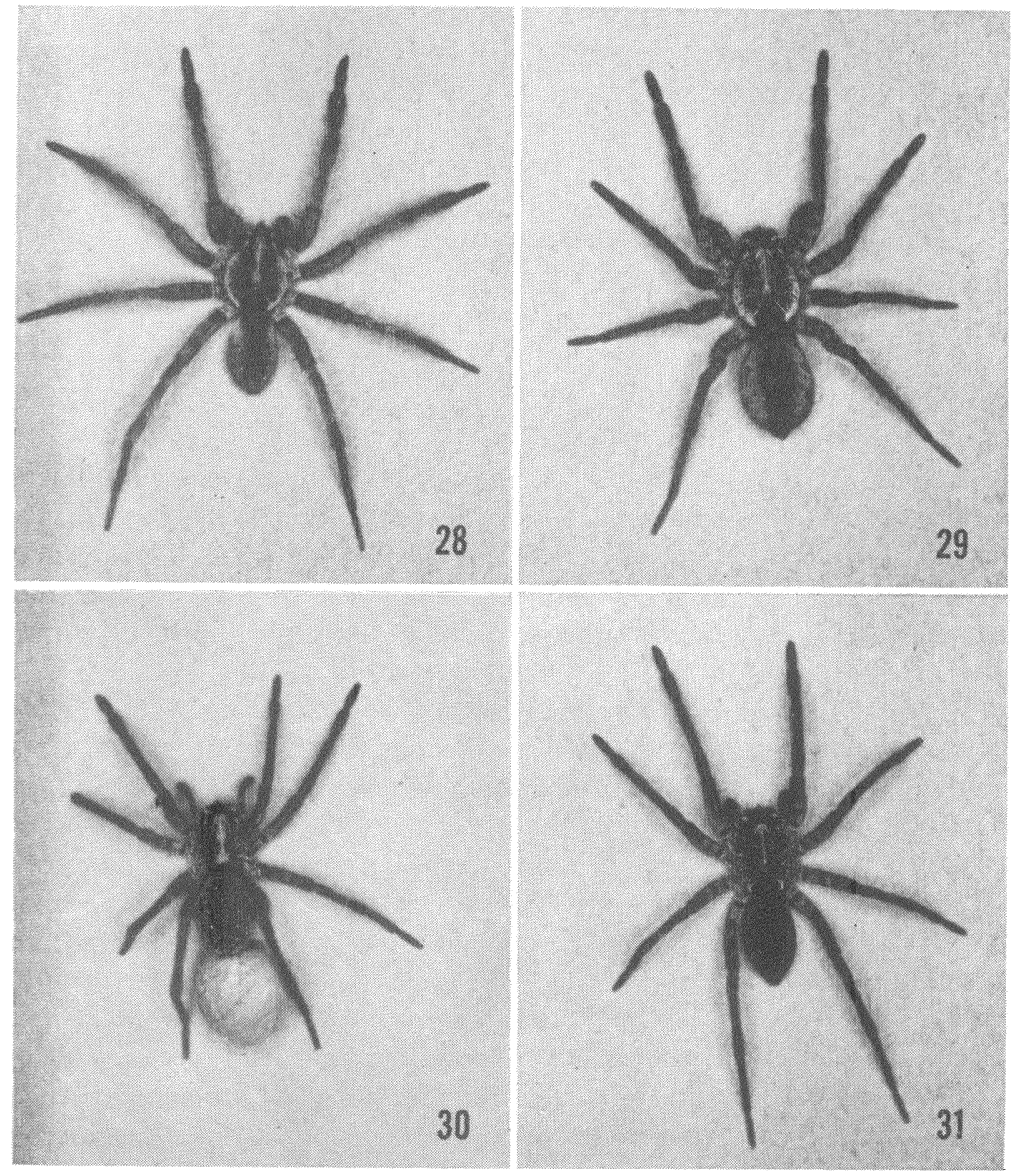

Figs. 28-30. Sosippus mimus Chamberlin, from Fountainbleau St. Pk., near Mandeville, St. Tammany Par., Louisiana, 17-18 June 1968. 28. Male. 29. Female. 30. Female with egg case.

Fig. 31. Female of Sosippus mimus Chamberlin, from Magnolia St. Pk. near Biloxi, Jackson Co., Mississippi, 18 June 1968. 
and garbage dumps. Tubular retreats were built at an angle into the sides of banks, ruts and furrows. Extending from the tubular portion is a sheet or platform web. Not uncommonly the tubular portion of the web would lead under a log or other cover in which cases it might extend for 9-12 inches $(23-30 \mathrm{~cm})$. The posterior end of this tube seems always to be open so that the spider can retreat if disturbed. Where the retreat dead-ends into a hole or depression, there is a side avenue of escape. The webs closely resembled those of Agelenopsis which also occurred in the same habitats. The specimens of Agelenopsis were immature, whereas most of the Sosippus were mature and some carried egg cases. The egg case is carried attached to the spinnerets as in other lycosids (Figs. 30, 38).

Immature specimens of $S$. mimus were taken from October I3, I969 through April 27, 1970 at Tall Timbers Research Station in pitfall traps. Males were recovered from May 4-June 22, 1970. Although collections continued through June 22, I970, only four females appeared in these traps - from May II through May 25.

Distribution. Western Florida to Louisiana (Map I).

Records. These constitute the only valid records for $\mathcal{S}$. mimus as it is defined here. FLORIDA. Bay Co.: $7 \mathrm{mi}$. S of Youngstown on US 231, 20 June $19680^{\pi}: 3$ 우 : 300 (A. R. Brady, J. Toothaker). Escambia Co.: I8 June 1934 oo (H. K. Wallace). Jackson Co.: 3 Apr. I953 ơ (H. K. Wallace). Leon Co.: Tall Timbers Research Station, I3 Oct. I969-22 June 1970 I2 $0^{x} 0^{x}$ : 4 우 : 500 (D. L. Harris). Liberty Co.: 2-4 June $19520^{\pi}$; Blountstown, I7 Apr. 1938 o (W. J. Gertsch). Suwanee Co.: 25 Mar. I933 $\sigma^{7}$ (H. K. Wallace). Saint Johns Co.: Hastings, July I927 $0^{\star}$ (J. L. Scribner). MISSISSIPPI. Forest Co.: Hattiesburg, 2-6 Jan 1942 oo (E. L. Bell). Jackson Co.: Magnolia St. Pk. near Biloxi, I8 June 1968 5우 (A. R. Brady, J. Toothaker); Ocean Springs, Io May I93 I $0^{7}$ (Dietrich). LOUISIANA. St. Tammany Par.: Fountainbleau St. Pk. near Mandeville, I7-I 8 June I968 $3 \sigma^{x} \sigma^{x}:$ I I 우우: o (A. R. Brady, J. Toothaker); Mandeville, I May ig2 i + (H. E. Hubert).

\section{Sosippus janus sp. $\mathrm{n}$.}

Figures 25-27, 40-3I. Map I

Sosippus mimus, - Brady, 1962, in part: fig. 17, not S. mimus Chamberlin.

Holotype. Female from NW shore of Lake Lochloosa, Alachua Co., Florida, Io June I968 (A. R. Brady, and J. Toothaker) de- 

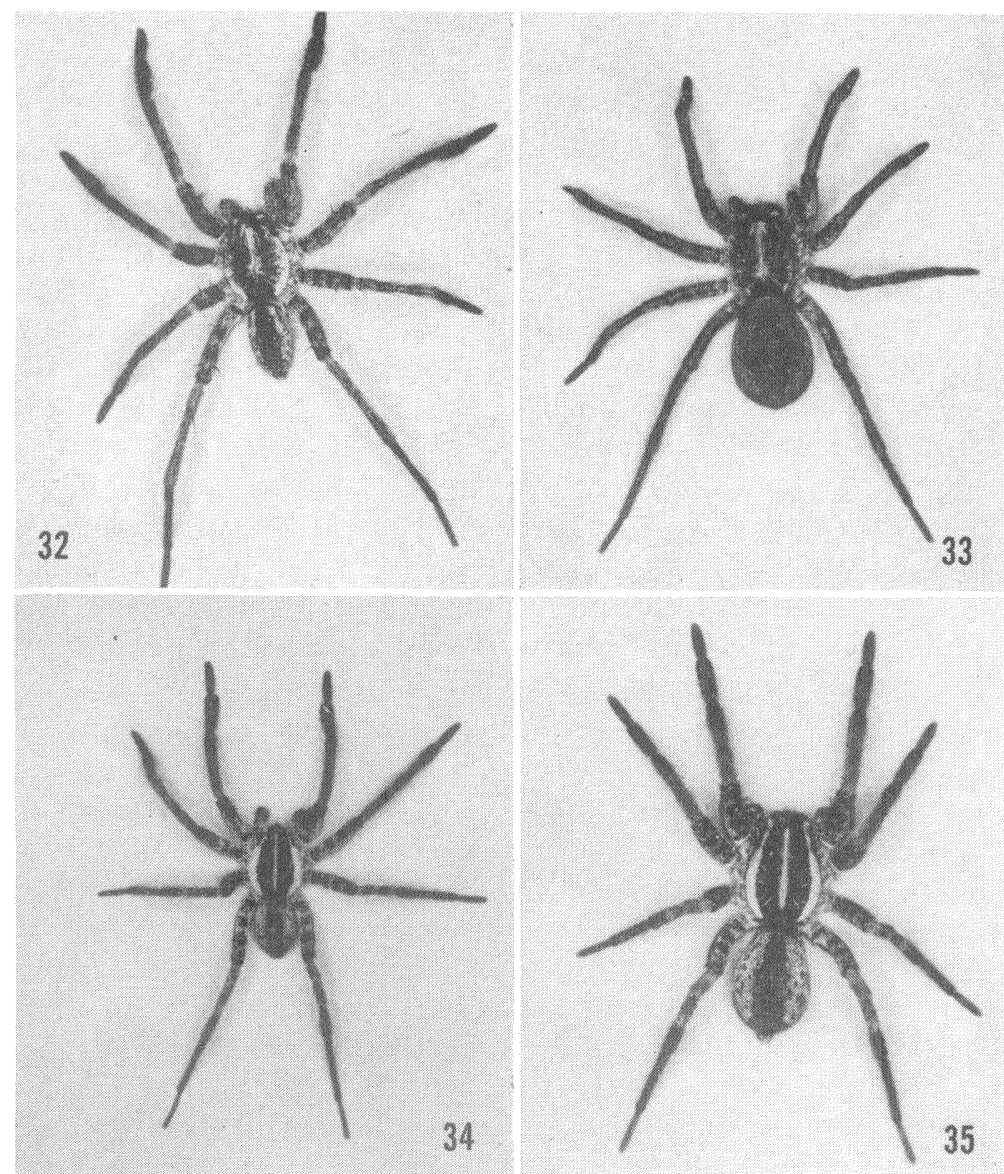

Figs. 32-33. Sosippus mimus Chamberlin, from $7 \mathrm{mi}$. S of Youngstown, Bay Co., Florida, 20 June 1968. 32. Male. 33. Female.

Figs. 34-35. Sosippus floridanus Simon, from Cedar Key, Levy Co., Florida, 9 June 1968. 34. Male. 35. Female. 
posited in the Museum of Comparative Zoology. The name is a noun in apposition after the Roman god.

Discussion. Sosippus janus is difficult to interpret at this time, primarily due to a lack of specimens from areas other than Lake Lochloosa. The geographic range of this species is unknown, but it appears to be limited to mesic habitats. Of the 36 specimens examined from the type locality some show deviation from the normal 4-4 pattern of posterior cheliceral teeth (Table I). However, this variation and the variation in epigynal structure (Figs. I4-I8) is no greater than one encounters in other large series of specimens from a single locality, for example $S$. mimus near Mandeville, Louisiana. It is possible that $S$. janus represents a geographic race or, perhaps, a hybrid zone between $S$. floridanus and $S$. mimus, but the present evidence indicates a distinct biological entity.

The female genitalia of $S$. janus are distinctive and the color pattern is unlike $S$. floridanus, which has the same number of posterior cheliceral teeth. In addition to structural differences, $S$. janus is found in mesic situations, like the Live Oak (Quercus virginiana) woodland of Figure 43, while $S$. floridanus is found in drier communities, such as the Pine and Palmetto association shown in Figure 42. Because of these distinctions the population at Lake Lochloosa is recognized as representative of a new species here.

Measurements. Total body length of five males from the type locality 9.9-I2.7 mm, mean I I.7O mm, carapace width 4.2-5.0 mm, mean $4.74 \mathrm{~mm}$, carapace length $5.7-6.5 \mathrm{~mm}$, mean $6.22 \mathrm{~mm}$.

Width of anterior eye row I.28-1.45 mm, mean I.370 mm. Posterior ocular quadrangle (POQ)*: PME width I.05-1.20 mm, mean I.1 $25 \mathrm{~mm}$, PLE width I.5O-I.73 mm, mean I.645 mm, POQ length .95-1.08 mm, mean $1.020 \mathrm{~mm}$.

Leg IV: femur 5.8-6.9 mm, mean $6.40 \mathrm{~mm}$, patella-tibia 7.I$8.2 \mathrm{~mm}$, mean $7.70 \mathrm{~mm}$, metatarsus $7.0-8.0 \mathrm{~mm}$, mean $7.58 \mathrm{~mm}$, tarsus 3.4-3.6 mm, mean $3.50 \mathrm{~mm}$, total length $22.3-26.7 \mathrm{~mm}$, mean $25.18 \mathrm{~mm}$.

Patella-tibiae: I $6.5-7.7 \mathrm{~mm}$, mean $7.18 \mathrm{~mm}$, II $6.2-7.2 \mathrm{~mm}$, mean $6.72 \mathrm{~mm}$, III $5.5-6.3 \mathrm{~mm}$, mean $5.98 \mathrm{~mm}$.

Total body length of 20 females from the type locality I2.4-I 5.8 mm, mean I $4.4 \mathrm{I} \mathrm{mm}$, carapace width $4.5-5.8 \mathrm{~mm}$, mean $5.19 \mathrm{~mm}$, carapace length 6.1-7.7 $\mathrm{mm}$, mean $7.01 \mathrm{~mm}$.

*The posterior median eyes (PME) and the posterior lateral eyes (FLE), which form two rows in the Lycosidae, are referred to in this paper as the posterior ocular quadrangle (POQ). Measurements of the $\mathrm{POQ}$ are diagrammed in Text Figure 1 of Brady 1962. 


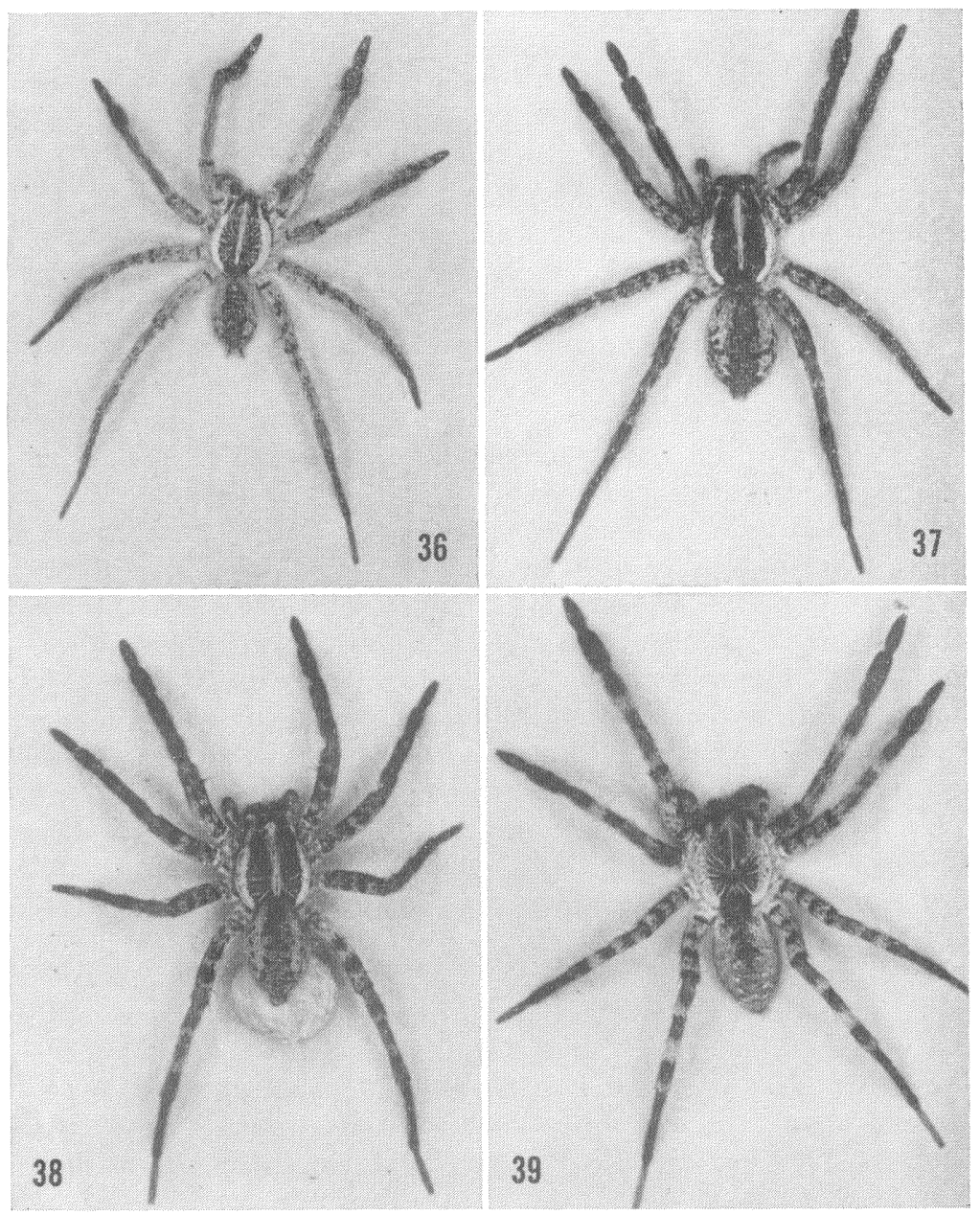

Figs. 36-38. Sosippus fioridanus Simon, from one mile E of Horse Creek on St. Highway 72, Desoto Co., Florida, 12 June 1968. 36. Male. 37. Female. 38. Female with egg case.

Fig. 39. Female holotype of Sosippus placidus sp. n., from $6 \mathrm{mi}$. S of Lake Placid, Highlands Co., Florida, 12 June 1968. 


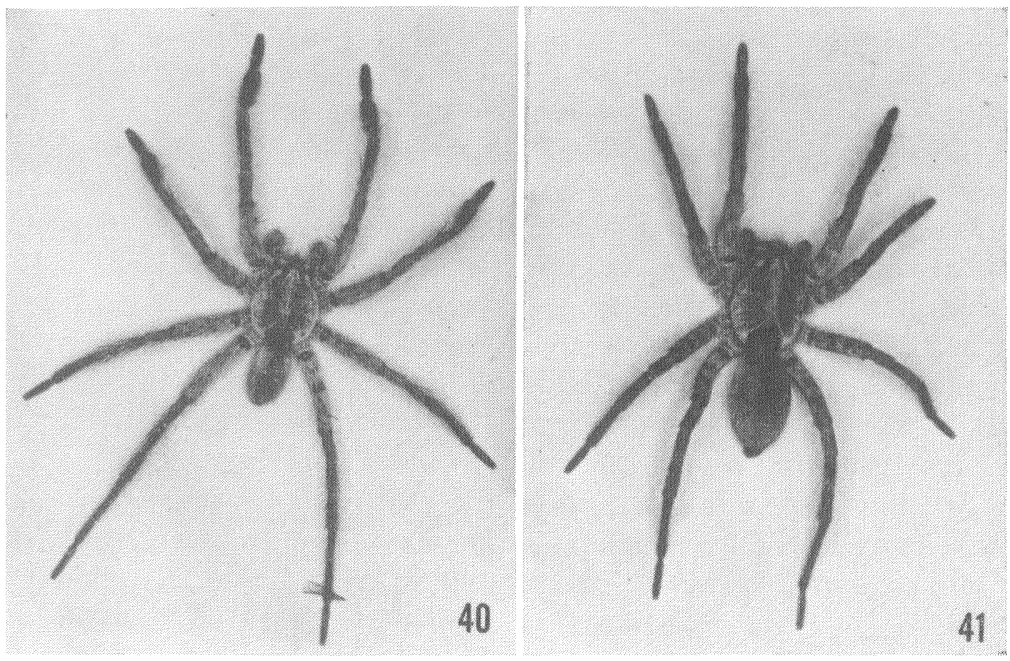

Figs. 40-41. Sosippus janus sp. n., from NW shore of Lake Lochloosa, Alachua Co., Florida, 6 Apr. 1972. 40. Male. 41. Female.

Width of anterior eye row I.43-1.73 mm, mean $1.598 \mathrm{~mm}$. Posterior ocular quadrangle (POQ): PME width I.I3-1.35 mm, mean I.268 mm, PLE width I.73-2.08 mm, mean $1.965 \mathrm{~mm}$, POQ length I.OO-I.25 mm, mean I.I $58 \mathrm{~mm}$.

Leg IV: femur 5.5-6.9 mm, mean 6.3 $\mathrm{mm}$, patella-tibia 6.4$8.2 \mathrm{~mm}$, mean $7.42 \mathrm{~mm}$, metatarsus $5.7-7.5 \mathrm{~mm}$, mean $6.64 \mathrm{~mm}$, tarsus 2.8-3.5 mm, mean 3.10 $\mathrm{mm}$, total length $20.4-26.1 \mathrm{~mm}$, mean $23.46 \mathrm{~mm}$.

Patella-tibiae: I $6.0-7.6 \mathrm{~mm}$, mean $6.80 \mathrm{~mm}$, II $5.5-7.0 \mathrm{~mm}$, mean $6.27 \mathrm{~mm}$, III $4.7-6.2 \mathrm{~mm}$, mean $5.50 \mathrm{~mm}$.

Color. Male. Pattern illustrated in Figure 40. Face dark reddish brown, with broad white stripes on each side extending from below PME diagonally downward toward cheliceral condyles. Eye region black. Chelicerae dark reddish brown, black distally. Palpi brownish yellow to brown.

Carapace reddish brown with three stripes of white hair in cephalic region: a median stripe beginning between PLE and extending to thoracic groove, a pair of white stripes beginning inside PLE continuing diagonally tangent to inner surface of PLE and then 
straight back to edge of cephalic region. Four pairs of dark lines radiating from thoracic groove. Edge of carapace heavily clothed with white hair, forming a light marginal stripe.

Dorsum of abdomen with broad median brown stripe, laterally and along the sides lighter, mottled brown with covering of white pubescence. Five pairs of white spots at edges of median stripe, the posterior three pair connected by white chevrons. Venter of abdomen with broad median yellowish brown stripe, bordered by light brown clothed with white pubescence. In some cases a pair of thin brown stripes are visible within the broader pale median one. These run lateral to the genital area and converge posteriorly.

Legs yellowish brown with faint dusky markings on femora, lighter yellowish ventrally, especially coxae.

Labium and endites orange to yellow-brown with distal ends pale yellow to cream. Sternum pale orange to light brownish yellow.

Female. Pattern illustrated in figure 4I. Face dark reddish brown with white hair from ALE to outer lower edge of clypeus.

Carapace reddish brown with margins of lighter color covered by white pubescence. White lines radiating from thoracic groove. A median white stripe from between PLE to thoracic groove and a pair of white stripes in cephalic region converging between PME.

Dorsum of abdomen with a wide dark brown median stripe bounded by lighter areas of brown intermixed with white pubescence. Four or five white chevrons sometimes discernible on posterior half. Venter of abdomen pale yellow to yellow brown above epigastric furrow, cream to brown below epigastric furrow and thickly clothed with white hair.

Legs yellow-brown to orange-brown, with coxae lighter, yelloworange on ventral surface.

Labium and endites dark brown with lighter yellowish distal ends. Sternum yellow-brown.

Fig. 42. Pine and Palmetto association one mile $\mathrm{E}$ of Horse Creek on St. Highway 72, Desoto Co., Florida, 12 June 1968. Habitat of Sosippus floridanus Simon.

Fig. 43. Mesic woodland on NW shore of Lake Lochloosa, Alachua Co., Florida, 20 June 1968. Type locality of Sosippus janus sp. $n$.

Fig. 44. Very dry clearing with Opuntia as the dominant vegetation, $6 \mathrm{mi}$. S of Lake Placid, Highlands Co., Florida, 12 June 1968. Type locality of Sosippus placidus sp. n.

Fig. 45. Close-up view of a sheet-web of Sosippus placidus with the retreat (in center of photograph) at the base of Opunsia. Same locality as in Figure 44. 

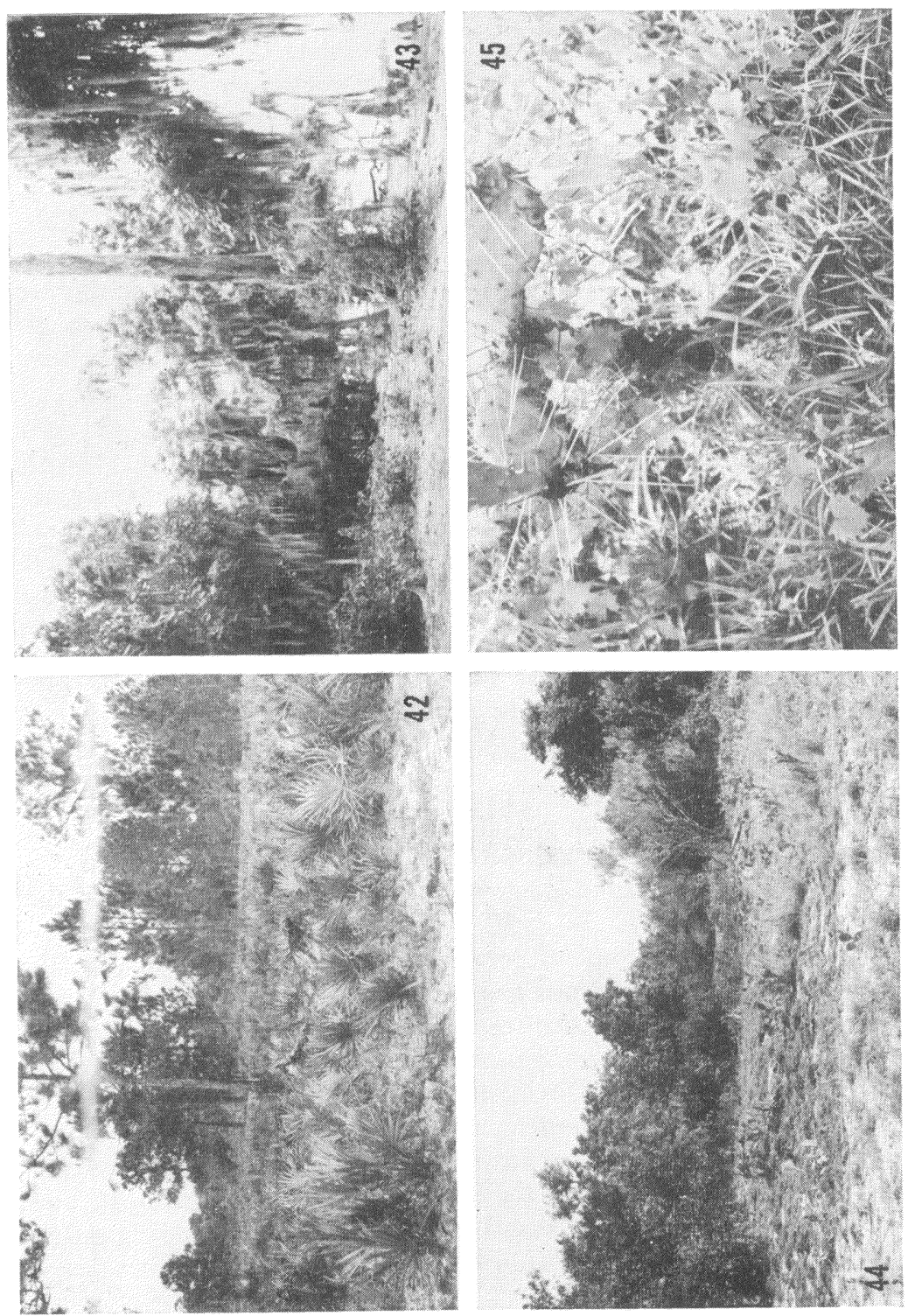
Diagnosis. Sosippus janus is similar to $S$. mimus in color pattern, but unlike that species, it has 4-4 cheliceral teeth and differs from $S$. mimus in epigynal structure (compare Figs. I4-18 with Figs. I9). The epigynum of $S$. janus is like that of $S$. floridanus (compare Figs. I4-I 8 with Figs. IO-I3), but with consistent differences between the two species. In addition, based on present information, $S$. janus is restricted to mesic habitats such as that surrounding Lake Lochloosa in Figure 43, while $S$. floridanus occurs in drier and more open habitats such as the Pine and Palmetto community in Figure 42. Thus, the color pattern of $S$. janus, the structure of the epigynum, and its habitat indicate reproductive isolation from $S$. floridanus and $S$. mimus.

Records. Florida. Alachua Co.: I8 Apr. 1935 900, I3 Apr. 1950 ㅇ (H. K. Wallace); NW shore of Lake Lochloosa, I I Apr. $196850^{x} 0^{x}:$ 우우: oo, 1о June 1968 г8우우:900 (A. R. Brady, J. Toothaker; $2.7 \mathrm{mi}$ W of Melrose, 13 June $1962 \sigma^{\pi} \sigma^{\pi}:$ ㅇ $: 400$ (A. R. Brady). Levy Co.: 20 Apr. 1935 ơ $o$ ㅇ oo (G. V. Hyn). Marion Co.: Kerr Park near Lake Kerr + (H. K. Wallace). Putnam Co.: 2 May 1947 o, 2-3 June 1947 foo (H. K. Wallace).

Sosippus placidus sp. $\mathrm{n}$.

Figures 25-27, 39. Map I.

Sosippus mimus, - Brady, 1962, in part: figs. 13, 14, not S. mimus Chamberlin.

Holotype. Female from 6 mi. S of Lake Placid, Highlands Co., Florida, I2 June I968 (A. R. Brady, J. Toothaker) in the Museum of Comparative Zoology. The species is named after the type locality.

Discussion. Two immature specimens and a single mature female of $S$. placidus were examined and described under $S$. mimus in 1962. The presence of a single mature female did not warrant description of a new species at that time. Because of the 3-3 pattern of posterior cheliceral teeth and their color pattern (in alcohol) these specimens were thought to represent a southern population of $\mathcal{S}$. mimus. The uniqueness of the single female's epigynum prompted a drawing of the female genitalia and these are illustrated in figures 13 and I4 of Brady (I962). Additional evidence now clearly indicates that this southern Florida population of Sosippus near Lake Placid represents a distinct species.

Measurements: Total body length of three females 15.0-17.6 $\mathrm{mm}$. Carapace width 5.3-6.3 mm, carapace length 7.7-9.1 mm.

Width of anterior eye row 1.63-1.88 mm. Posterior ocular quad- 
rangle: PME width I.38-1.55 $\mathrm{mm}$, PLE width 2.05-2.43 mm, POQ length I.2O- $1.40 \mathrm{~mm}$.

Leg IV: femur 7.3-8.6 mm, patella-tibia 8.6-10.3 mm, metatarsus 7.5-8.9 mm, tarsus 3.3-4.0 mm, total length 26.7-31.8 mm.

Patella-tibiae: I 7.9-9.5 mm, II 7.6-9.I mm, III 6.5-7.9 mm.

Color. Female. Pattern illustrated in Figure 39. Face dark reddish brown, black in eye region, with white hair at outer lower margins. Chelicerae black.

Carapace dark reddish brown with broad marginal stripes of paler orange-brown due to covering of white hair. Pattern of dark lines radiating from thoracic groove accented by white hair.

Dorsum of abdomen dark brown with five pairs of white spots connected by white chevrons on posterior half. Venter of abdomen bright yellow-orange.

Legs brown with alternating light and dusky bands. Coxae and trochanters bright orange, conspicuously so on ventral surfaces.

Labium and endites dark red-orange with lighter yellowish distal ends. Sternum bright yellow-orange.

Diagnosis. Sosippus placidus is recognized by its 3-3 posterior cheliceral teeth, a striking red-orange ventral surface, and a distinct epigynum (Figs. 25-27). It differs from $S$. floridanus, its closest neighbor geographically, in number of cheliceral teeth (Table I), color pattern (compare Fig. 39 with Figs. 34-38), and epigynal structure (compare Figs. 25-27 with Figs. IO-I3, I9-24). Sosippus placidus agrees with $S$. mimus in number of posterior cheliceral teeth (Table I), but is distinguished from that species by its different color (red-orange ventral surface), distinct epigynum (compare Figs. 25-27 with Figs. I-9) and geographic location (Map I). In addition to its morphological distinctness, $S$. placidus appears to have a different breeding season than the populations of $S$. floridanus occurring in its vicinity and also different habitat requirements. Sosippus placidus was collected in a very dry area of scrub vegetation, including Opuntia (Figs. 44-45). This area was represented by Red Hill Island during the Aftonian Interglacial (Laessle, I958) and the restricted occurrence of this species seems to be directly related to its former insular distribution. For an analysis of the evolutionary factors that played a key role here, see the section on Geographic Variation and Speciation in this paper.

Records. Florida. Highlands Co.: Archibold Biological Station near Lake Placid, 24 Jan.-4 Feb. 1943 foo (M. Cazier), 6 mi. $\mathrm{S}$ of Lake Placid, I2 June I968 3워:700 (A. R. Brady, J. Toothaker). 


\section{References Cited}

BRADY, A. R.

1962. The spider genus Sosippus in North America, Mexico, and Central America (Araneae, Lycosidae). Psyche, 69(3): 129-164. Laessle, A. M.

1958. The origin and successional relationship of sandhill vegetation and sand-pine scrub. Ecol. Monographs, 28: 361-387.

MCCrone, J. D.

1963. Taxonomic status and evolutionary history of the Geolycosa pikei complex in the southeastern United States (Araneae, Lycosidae). Amer. Midland Nat., 70(1): 47-73.

McCrone, J. D. and H. W. Levi

1964. North American Widow spiders of the Latrodectus curacaviensis group (Araneae: Theridiidae). Psyche, 71(1): 12-27.

ROEWER, C. F.

1959. Lycosaeformia II (Lycosidae). Exploration du Parc National de l'Upemba. Brussels, 2: 519-1040. 

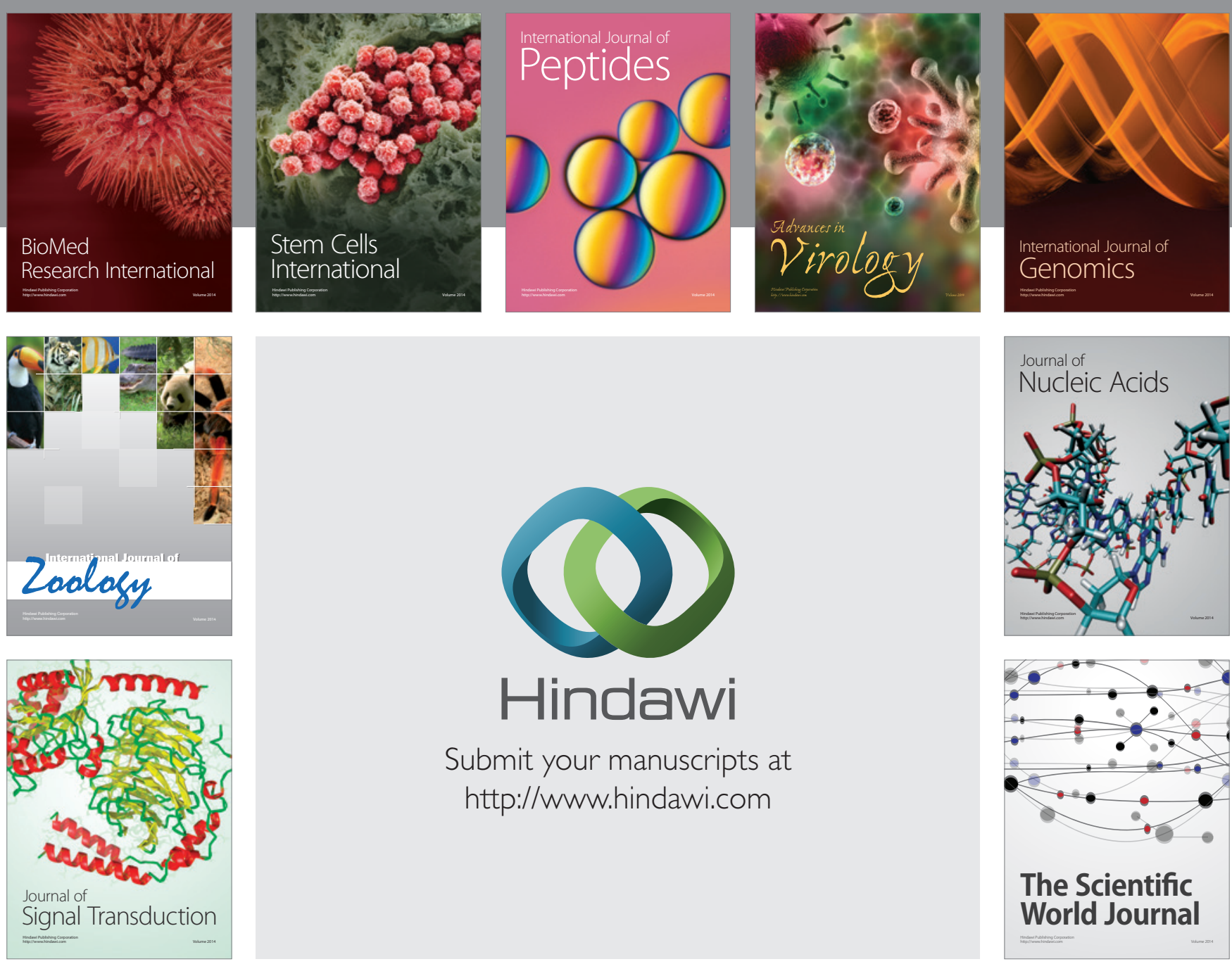

Submit your manuscripts at

http://www.hindawi.com
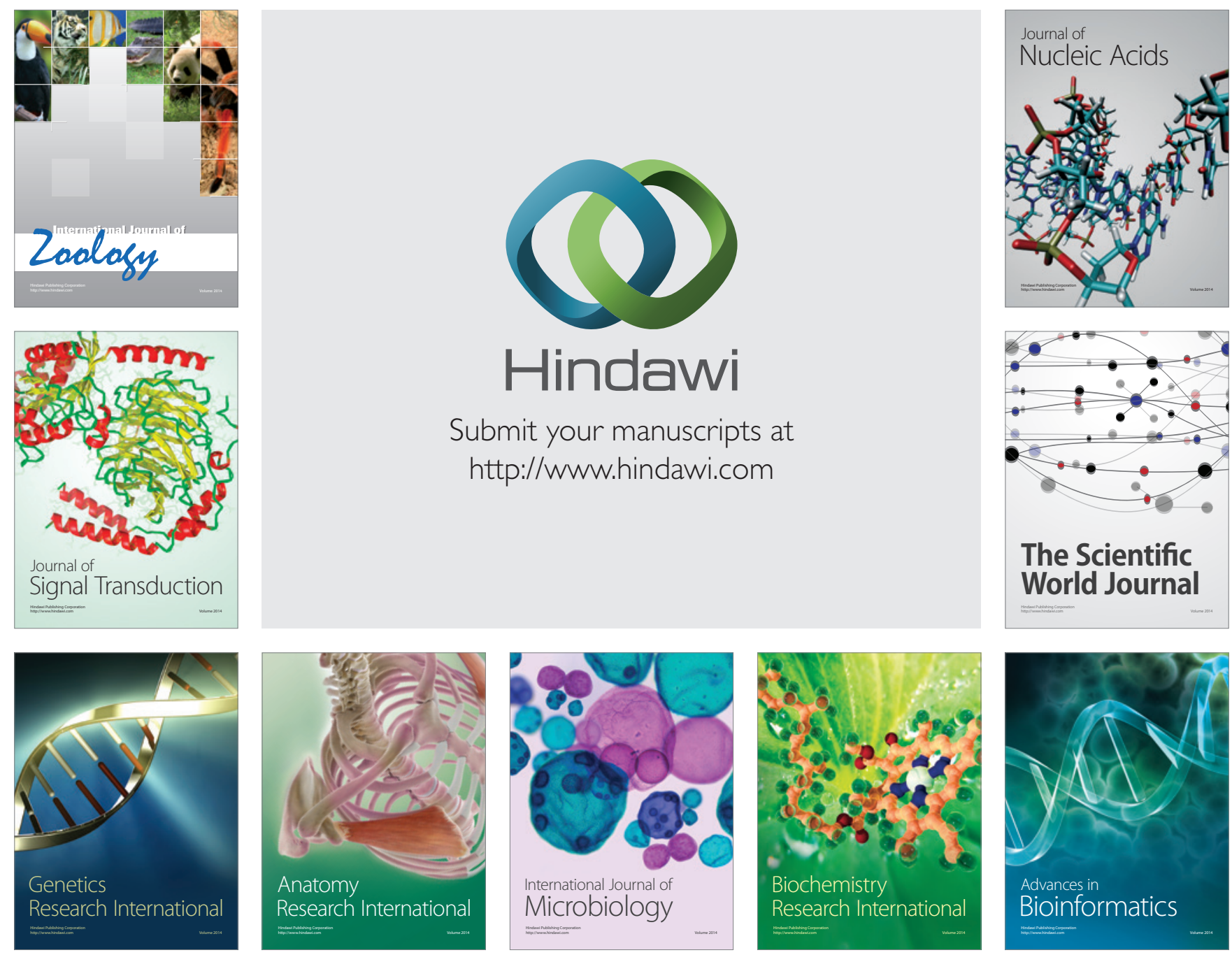

The Scientific World Journal
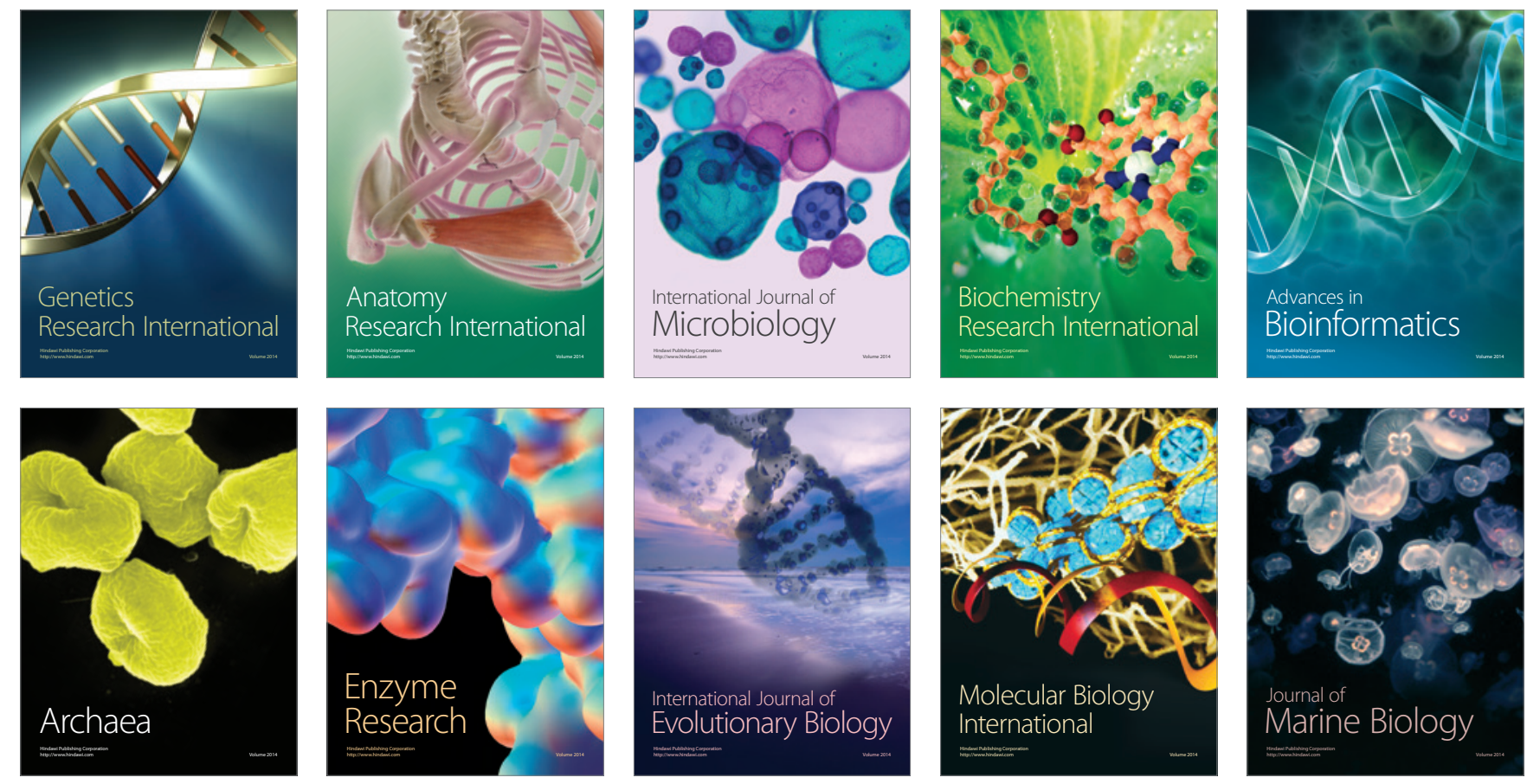